\title{
REVIEW
}

\section{The Mediators of Bile Action on the Exocrine Pancreas*}

In a recent review (1) evidence was presented that intraduodenally applied bile and certain bile salts dose-dependently increase basal and hormonally stimulated hydrokinetic and ecbolic pancreatic function in man and animals. In contrast, bile and bile salts have no effect or even reduce pancreatic secretion stimulated by intraduodenal nutrient compounds. Moreover, species differences, particularly with regard to the rat, have been discussed.

A direct action of bile salts on the pancreas via the circulation is very unlikely, since the effects of bile salts occur immediately after intraduodenal application. Bile salts, however, are physiologically absorbed in the terminal ileum. Therefore, hormones and/or neural mechanisms must be assumed to be mediators.

\section{HORMONAL MEDIATORS}

In this section, gastroenteropancreatic peptides released by bile or bile salts will be discussed in accordance with their action on the exocrine pancreatic secretion.

Gastroenteropancreatic peptides with stimulatory effects

Secretin. Secretin is the most important hormonal mediator of pancreatic volume and bicarbonate secretion $(2,3)$. Its effect can be enhanced by other hormones, such as cholecystokinin (CCK), and by neural mechanisms (4).

As early as in 1926, Mellanby (5) proposed the existence of a mediator role for secretin in bile-induced pancreatic secretion in anaesthetized cats. Some 50 years later Osnes et al. $(6,7)$ were the first to show that intraduodenal application of $6 \mathrm{~g}$ of cattle bile induces a significant increase not only of pancreatic volume and bicarbonate secretion but also of plasma secretin levels in man. A load of $4 \mathrm{~g}$ of bile followed by a constant infusion of $0.15 \mathrm{~g}$ bile $/ \mathrm{min}$ over a 40 min period continuously released secretin and stimulated pancreatic secretion as well (8). In addition, plasma secretin concentrations rose significantly after intraduodenal application of 2,4 , and $6 \mathrm{~g}$ bile at 65 -min intervals, and the kinetics of plasma secretin was correlated to that of volume and bicarbonate secretion (9). Moreover, integrated plasma secretin showed a dose-dependent increase after bile, indicating a specific effect of bile on secretin release (9). Burhol et al. (10), however, found only a non-significant increase of plasma secretin on intraduodenal infusion of $6 \mathrm{~g}$ bile in man. On the other hand, an intravenous injection of cholecystokinin (CCK), a potent stimulus of gallbladder

\footnotetext{
* Dedicated to Professor M.M. Forell.
}

contraction, did not influence plasma secretin concentrations in man (11). The bile secretion, however, was not measured in these experiments. In contrast, in the anaesthetized cat, instillation of gallbladder bile in the duodenum significantly increased plasma secretin concentrations (12).

Bile salts are the effective constituents of bile with regard to stimulation of basal pancreatic secretion (1). A solution of pure synthetic bile salts $(20 \mathrm{ml}$ of a $50-\mathrm{mM}$ solution), comparable to human gallbladder bile, increased plasma secretin levels significantly in man (13). Furthermore, intraduodenally infused solutions of single bile salts (up to $90 \mathrm{mM}$ ), like Na-glycocholate, Na-cholate, Na-taurocholate, and chenodeoxycholate significantly and dose-dependently enhanced plasma secretin concentrations (11). The relative secretin-releasing potencies of these bile salts in the order mentioned above are 1:1.3:1.9:3.2. Pancreatic hydrokinetic function, however, was not measured simultaneously in these studies $(11,13)$. In a recent study in man $(9)$, not only a dose-dependent increase of integrated plasma secretin but also a corresponding dose-dependent augmentation of volume and bicarbonate secretion after 200,400 , and $600 \mathrm{mg}$ Na-taurodeoxycholate could be observed.

The kind of conjugation (taurine or glycine) does not influence the hydrokinetic activity and the secretin-releasing potency of deoxycholate (14). In contrast, taurocholate showed a 1.9-fold greater secretin release than glycocholate. The hydrokinetic effect was not registered (11).

In anaesthetized cats duodenal perfusion $(45 \mathrm{ml} / \mathrm{h})$ with Na-taurocholate $(120 \mathrm{mM})$, the predominant bile salt in this species, increased plasma secretin concentrations and pancreatic flow as well (15). The threshold concentration of $\mathrm{Na}$ taurocholate for secretin release was between 10 and $15 \mathrm{mM}$ (12). In rats, the hydrokinetic effect of chenodeoxycholate was markedly reduced by an intravenous injection of a specific secretin antibody (16).

From these results it may be concluded that secretin acts as a mediator of the hydrokinetic effect of bile and bile salts on basal pancreatic secretion.

In contrast to basal (interdigestive) conditions, the secretin-releasing effect of Na-taurocholate was significantly diminished when the bile salt was dissolved in a liquid meal instead of a saline solution in man (11). Reinfusion of postprandial aspirate containing $15.8 \mathrm{mM}$ endogenous bile salts did not influence plasma secretin concentrations. Enhancing total bile salt concentration up to $30 \mathrm{mM}$ by addition of chenodeoxycholate, however, resulted in an immediate increase of plasma secretin levels (11). Whether the content of bile salt monomers is reduced during the meal 
by micelle formation and increased again after the addition of chenodeoxycholate to a load releasing secretin is speculative. After intragastric application of a liquid meal, however, no correlation was found between the duodenal load of bile acids and plasma secretin concentrations (17). These data are in accordance with the hypothesis that bile and bile salts do not stimulate nutrient-induced pancreatic secretion (1).

Vasoactive intestinal peptide (VIP). VIP, a partial agonist of secretin, acts as a hormonal mediator of hydrokinetic pancreatic function when infused in pharmacologic doses $(18,19)$. Under physiologic conditions, however, VIP may act as a peptidergic neurotransmitter. Since the existence of VIP-containing endocrine cells of the gut is questioned as well (20), a hormonal action of VIP on the exocrine pancreas is unlikely. An increase in peripheral VIP levels represents rather a neuronal 'overflow' phenomenon (21). Therefore, changes in plasma VIP levels after bile and bile salts will be discussed below (see section on peptidergic mechanisms).

Cholecystokinin. CCK is the essential hormonal stimulus of pancreatic enzyme secretion (4). In man, only a few data are available about bile- or bile salt-induced CCK release. A physiologic dose of Na-taurodeoxycholate $(0.8 \mathrm{mmol})$ applied intraduodenally caused a significant increase of plasma CCK concentrations (22). In earlier studies by Burhol et al. $(23,24)$, however, bile, intraduodenally infused in a submaximal dose with regard to the stimulatory effect on the exocrine pancreas (9), did not affect plasma CCK levels. This discrepancy may be due to a different sensitivity and specificity of the CCK radioimmunoassays used. On the other hand, in patients with a common bile duct obstruction due to a malignant tumour, basal CCK concentrations have been reported to be either increased (25) or normal (26).

In conscious starved dogs, perfusion of the duodenum with a 3.6- and $12-\mathrm{mM}$ solution of taurocholate $(100 \mathrm{ml} / \mathrm{h})$ left plasma CCK levels unchanged, although protein output of the pancreas was increased (27). Intraduodenal infusion of a very high amount of bile even reduced basal plasma CCK levels (28). Furthermore, diversion of bile from the duodenum and reinfusion to the jejunum (29) or external drainage (28) influenced neither basal plasma CCK nor pancreatic secretion.

In conscious starved rats without diversion of bile and pancreatic juice, intraduodenal infusion of chenodeoxycholate $(60 \mathrm{mmol} / \mathrm{l} ; 1 \mathrm{ml} / \mathrm{h})$ significantly enhanced pancreatic protein output but not plasma CCK. Administration of the specific CCK antagonist CR-1409, however, significantly reduced the ecbolic effect, suggesting that $\mathrm{CCK}$ plays at least some role in the mediation of the bile salt effect in this species (16).

In contrast to basal conditions, nutrient-induced pancreatic enzyme secretion is reduced by intraduodenal bile or bile salts in man, suggesting an impaired CCK release $(1,30)$. In accordance with this hypothesis, Gomez et al. (31) noted a significant decrease of plasma CCK-33/39 after oral in- gestion of an amino acid solution when adding $6 \mathrm{mmol}$ of taurocholate. Furthermore, 5 and $10 \mathrm{mmol}$ of chenodeoxycholate decreased CCK release produced by an orally ingested or duodenally perfused liquid test meal $(26,32)$.

In dogs, CCK-33/39 release stimulated by intraduodenal instillation of amino acids and triglycerides was inhibited by addition of pooled bile and enhanced by diversion of bile from the duodenum $(28,31)$. The latter effect could be completely reversed by substituting exogenous bile salts. Furthermore, taurocholate added to an intraduodenally perfused fat solution reduced both integrated CCK release and pancreatic protein output (27). In contrast, diversion of bile from the duodenum by cholecystojejunostomy and bile duct ligation decreased meal-stimulated CCK release and trypsin secretion rate (29). There is no conclusive explanation for these discrepancies.

In rats, a luminal feedback regulation of pancreatic secretion is assumed not only due to protease activity, but also with regard to bile $(33,34)$. Diversion of bile, pancreatic juice, or both from the intestine enhanced plasma $\mathrm{CCK}$ levels and pancreatic protein output as compared with the basal value (35). Conversely, the effects could be impaired by intraduodenal infusion of several bile salts $(16,36)$. Chronic experiments with bile duct ligation also increased basal plasma CCK concentrations (37). On the other hand, intraduodenal Na-taurocholate did not inhibit CCK release and pancreatic secretion in rats with chronic diversion of bile and pancreatic juice (38). This discrepancy may be due to the difference in experimental design (bile duct ligation versus external drainage of bile and pancreatic juice).

In mice without exclusion of bile or pancreatic juice, meal-stimulated CCK release was also reduced by chronic intraduodenal application of Na-taurocholate (39).

Cholestyramine is a bile salt-binding resin (40) and therefore a valuable tool to elucidate further the effect of intraduodenal bile salts on CCK release and pancreatic secretion. Chronic oral treatment with $12 \mathrm{~g}$ cholestyramine three times daily in man significantly increased basal plasma CCK concentrations after the first day, but this effect was attenuated and finally abolished after 4 weeks. Basal enzyme secretion, however, remained unchanged (41). In conscious dogs continuous intraduodenal infusion of $8 \mathrm{~g} / \mathrm{h}$ of cholestyramine influenced neither plasma CCK-33/39 levels nor protein output (31). In guinea pigs and rats, long-term intraduodenal application of cholestyramine did not affect basal plasma CCK concentrations $(42,43)$. In contrast, CCK release and pancreatic enzyme output stimulated by nutrient compounds were enhanced by oral or intraduodenal administration of cholestyramine in man $(31,32,41,44)$, dogs (31), guinea pigs (42), rats (43), and mice (39). The effect on CCK release could be abolished by adding taurocholate (31) or chenodeoxycholate (45) to the stimulants.

An interpretation of the conflicting results about intraduodenal bile or bile salts on CCK release seems to be difficult. Although bile or bile salts stimulate basal enzyme 
secretion, a release of CCK could be demonstrated only by a recent study, whereas in earlier investigations no changes of plasma CCK were observed. CCK radioimmunoassays used in the latter studies, however, showed a low sensitivity and specificity. As another explanation for the lack of CCK release, the hypothesis stated by Singer may be cited (4). Accordingly, high loads of intraduodenal stimulants of the exocrine pancreas may predominantly be mediated by hormones; low loads, however, are mediated by neural mechanisms.

In contrast to basal conditions, intraduodenal bile or bile salts seem to exert an inhibitory action on CCK release and on pancreatic enzyme secretion stimulated by intraluminal nutrient compounds. These observations are supported by the results obtained with cholestyramine. Removal of bile salts from the intestine by this resin enhances CCK release and pancreatic enzyme secretion stimulated by nutrient compounds. When evaluating the results, species differences have to be considered especially with regard to the rat. In this species, bile salts seem to exert an inhibitory effect on basal pancreatic enzyme secretion and on plasma CCK levels as well.

Neurotensin. Besides its neurotransmitter function, neurotensin is also a gastrointestinal hormone predominantly located in the ileum. The peptide increases basal hydrokinetic and ecbolic pancreatic secretion and augments the action of endogenously released secretin and CCK stimulated by $\mathrm{HCl}$ and amino acids, respectively $(46,47)$.

In starved dogs, neither intraduodenal application of bile nor bile diversion from the duodenum significantly influenced plasma neurotensin levels (28). Triglyceride-induced neurotensin release, however, was significantly enhanced by diversion of bile from the intestine. The effect is probably due to a delayed absorption with exposure of a longer part of the gut to fat rather than to an inhibitory action of bile on neurotensin release, since addition of bile did not diminish triglyceride-induced neurotensin release (28). In contrast, neurotensin release was further increased by addition of $2 \mathrm{~g}$ chenodeoxycholate to a cholestyramine-supplemented meal in man (48).

The contradictory results are probably due to species differences. Further studies, however, are needed to specify the releasing mechanisms of neurotensin and the role of bile.

Gastroenteropancreatic peptides without physiologic effect (on the exocrine pancreas)

Gastric inhibitory polypeptide $(G I P)$. In its primary structure, GIP is related to secretin and VIP. In physiologic doses, however, this peptide exerts no effect on the exocrine pancreas (49). After intraduodenal application of $6 \mathrm{~g}$ of bile in man plasma concentrations of GIP were moderately increased $(10,50)$, whereas duodenal perfusion with $\mathrm{Na}$ taurocholate showed no influence (51). In dogs, administration of bile into the upper jejunum left plasma GIP levels unchanged $(52,53)$.
In spite of the few studies, bile does not seem to be an essential stimulus of GIP release.

Gastrin. In physiologic doses, gastrin does not influence exocrine pancreatic secretion (54). Intraduodenal application of bile or Na-taurodeoxycholate caused only a marginal, dose-independent increase of plasma gastrin concentrations in man $(9,14,55,56)$. Furthermore, intraduodenal perfusion with Na-taurocholate did not enhance plasma gastrin levels and pancreatic secretion (51). In dogs, bile infusion into the upper jejunum left plasma gastrin concentrations unchanged (52). Diversion of bile from the duodenum by cholecystojejunostomy and bile duct ligation caused a late rise in serum gastrin levels and a decrease in trypsin secretion $(29,57)$. In contrast, by-passing bile into the ileum decreases gastrin release (58).

From these data it can be concluded that gastrin does not play any role in the mediation of the bile effect on pancreatic secretion.

\section{Gastroenteropancreatic peptides with an inhibitory effect}

Somatostatin. In a dosage reproducing postprandial plasma levels, somatostatin is able to inhibit exocrine pancreatic secretion, indicating its physiologic counterregulatory action (59). In man, intraduodenal application of 2 to $6 \mathrm{~g}$ bile and 200 to $600 \mathrm{mg} \mathrm{Na}$-taurodeoxycholate dosedependently increased plasma somatostatin concentrations simultaneously with a stimulation of exocrine pancreatic secretion (60). Somatostatin levels observed after the respective highest dose were in the range of postprandial concentrations. In contrast, Burhol et al. (61) were not able to show a significant rise in peripheral plasma somatostatin after intraduodenal application of $3 \mathrm{~g}$ bile.

In dogs, intraduodenal infusion of $3 \mathrm{~g}$ bile induced a marked release of somatostatin in portal plasma comparable to that found after intragastric fat infusions (62).

Although there are only a few studies, a physiologically relevant release of somatostatin by bile or bile salts may be assumed.

Pancreatic polypeptide (PP). PP is released by a meal or nutrient compounds. The release is mediated by cholinergic mechanisms and CCK. In physiologic doses PP exerts an inhibitory action on exocrine pancreatic secretion (63). In man, intraduodenal application of 2 to $6 \mathrm{~g}$ bile and 200 to $600 \mathrm{mg} \mathrm{Na}$-taurodeoxycholate dose-dependently increased not only exocrine pancreatic secretion but also plasma PP concentrations (9). Postprandial PP levels, however, were not reached. The PP-releasing effect was independent of the mode of conjugation (14). On the other hand, intraduodenal Na-taurocholate influenced neither plasma PP levels nor pancreatic enzyme secretion (51). Addition of $2 \mathrm{~g}$ chenodeoxycholate to a Lundh meal did not modify plasma PP levels, although trypsin output was significantly enhanced (44). Six grams of cholestyramine left meal-stimulated PP release unchanged (44), whereas $12 \mathrm{~g}$ of this resin caused a twofold increase (41). The latter induced higher plasma 
CCK levels, probably being responsible for the PP release observed.

From these studies it may be concluded that PP is only of minor importance as a counterregulatory hormone of the bile effect on pancreatic secretion.

\section{NEURAL MEDIATION}

\section{Cholinergic mechanisms}

Pancreatic hydrokinetic and ecbolic function is enhanced by cholinergic stimulation $(4,64,65)$. Furthermore, cholinergic mechanisms may enhance the action of endogenously released secretin and CCK. Only two studies, however, have been carried out to reveal the role of cholinergic mechanisms in the bile- or bile salt-induced exocrine pancreatic secretion.

In man, atropine clearly reduced the ecbolic effect of intraduodenal bile (66). Pancreatic enzyme secretion stimulated by 2 to $6 \mathrm{~g}$ intraduodenal bile could be almost completely abolished by propantheline, an anticholinergic drug with an additional ganglionic-blocking effect $(66,67)$. On the other hand, volume and bicarbonate secretion were not changed. There is, however, no information about the suppression of the cholinergic tone influencing the action of $\mathrm{CCK}$, as the effect of the anticholinergic drugs on CCKinduced pancreatic secretion was not investigated simultaneously.

PP is considered a hormone under vagal control (68) and may thus serve as an indirect marker of the involvement of cholinergic mechanisms. Indeed, plasma PP concentrations dose-dependently increased after intraduodenal bile and taurodeoxycholate, and the kinetics was correlated to that of trypsin secretion rate (9). However, PP is also released by CCK (69). Nevertheless, the amount of CCK concomitantly released by $\mathrm{Na}$-taurodeoxycholate may not be adequate to explain the PP release observed.

Considering these studies, the ecbolic effect of bile may at least partially be mediated by cholinergic mechanisms. On the other hand, cholinergic mechanisms do not seem to play an essential role in the mediation of the hydrokinetic action.

\section{Adrenergic mechanisms}

Sympathetic nerves probably are not involved in the postprandial pancreatic secretion (70). With regard to the bileor bile salt-induced pancreatic secretion no data are available about the influence of the sympathetic nervous system.

\section{Peptidergic mechanisms}

Besides the classical neurotransmitters, a third group consisting of several regulatory peptides has been established. In the pancreas, VIP-containing nerve endings have been detected. They are localized in close association with the pancreatic ducts (71) responsible for water and bicarbonate secretion. Moreover, in the isolated pig pancreas, electric stimulation of the vagus nerve caused a VIP release and an atropine-resistant hydrokinetic response as well $(71,72)$. Therefore, VIP may play a physiologic role in the mediation of water and bicarbonate secretion (73).

Intraduodenal application of a single dose of $6 \mathrm{~g}$ bile significantly enhanced plasma VIP levels and hydrokinetic pancreatic function in man (10). Moreover, 2, 4, and $6 \mathrm{~g}$ bile dose-dependently increased plasma VIP concentrations and integrated VIP concomitantly with volume and bicarbonate secretion (60). This rise in peripheral plasma VIP concentrations may be explained by an 'overflow' phenomenon of VIP from the synaptic cleft into the venous effluent. Therefore, VIPergic nerves may be involved in the mediation of the hydrokinetic effect of bile, although VIP is only a weak stimulus as compared with secretin (74). As bile was applied into the duodenum, the possibility cannot be completely excluded, however, that VIP measured in peripheral plasma partly originated from VIPergic neurons of the submucous or the myenteric plexus of the gut.

Gastrin-releasing peptide (GRP), a further regulatory peptide localized in nerve fibre endings of the pancreas, is able to stimulate pancreatic secretion (75). Studies on the effect of bile or bile salts on GRP release, however, have not yet been performed.

\section{SUMMARY}

Under basal conditions, bile and bile salts applied intraduodenally influence plasma levels of several gastroenteropancreatic peptides. Besides those with stimulatory effects on exocrine pancreatic secretion, others with inhibitory or no effects are released as well. Furthermore, cholinergic and peptidergic neural mechanisms may also be activated. Secretin seems to be the most important mediator of bile- or bile salt-induced water and bicarbonate secretion. In addition, VIP released from peptidergic nerve endings in the pancreas may also be involved in the mediation of the hydrokinetic effect. With regard to water and bicarbonate secretion, cholinergic mechanisms probably are of minor importance.

Cholinergic mechanisms, however, seem to be the most important mediator of bile- or bile salt-induced pancreatic enzyme secretion. CCK may act as an additional mediator of the ecbolic effect. This statement, however, is based on few results only and has to be confirmed by further studies.

Gastroenteropancreatic peptides with an inhibitory action on the exocrine pancreas were also released by intraduodenal bile or bile salts. Somatostatin is released in physiologically relevant amounts to bring about a counter-regulation. Plasma PP levels are also enhanced by bile and bile salts. The amounts of PP released, however, are below those observed postprandially.

In contrast to their stimulatory action on basal pancreatic secretion, bile and bile salts have no or even an inhibitory effect on pancreatic secretion stimulated by intraluminal nutrients. Accordingly, the release of gastroenteropan- 
creatic peptides is not influenced (for example, secretin) or even reduced (for example, CCK) when bile or bile salts are added to intraluminal nutrients. Conversely, removal of bile salts from the intestine by cholestyramine further enhances plasma CCK concentrations during nutrient stimulation.

R. L. RIEPL
P. LEHNERT
Medical Clinic
Klinikum Innenstadt
University of Munich
Munich, Germany

\section{REFERENCES}

1. Riepl RL. Lehnert $P$. The role of bile in the regulation of exocrine pancreatic secretion. Scand J Gastroenterol 1992;27: $625-31$.

2. Häcki WH. Secretin. Clin Gastroenterol 1980;9:609-32.

3. Solomon TE. Regulation of pancreatic secretion. Clin Gastroenterol 1984;13:657-78.

4. Singer MV. Pancreatic secretory response to intestinal stimulants: a review. Scand J Gastroenterol 1987;22 Suppl 139:1-13.

5. Mellanby J. The secretion of pancreatic juice. J Physiol 1926; 61:419-35.

6. Osnes M, Hanssen LE, Flaten O, Myren J. Exocrine pancreatic secretion and immunoreactive secretin (IRS) release after intraduodenal instillation of bile in man. Gut 1978;19:180-4.

7. Osnes $M$, Hanssen LE, Lehnert $P$, et al. Exocrine pancreatic secretion and immunoreactive secretin release after repeated intraduodenal infusions of bile in man. Scand $J$ Gastroenterol 1980;15:1033-9.

8. Osnes M, Hanssen LE. The influence of intraduodenal administration of pancreatic juice on the bile-induced pancreatic secretion and immunoreactive secretin release in man. Scand $\mathrm{J}$ Gastroenterol 1980;15:1041-7.

9. Riepl RL, Lehnert P, Scharl A, et al. Effect of intraduodenal bile and Na-taurodeoxycholate on exocrine pancreatic secretion and on plasma levels of secretin, pancreatic polypeptide, and gastrin in man. Scand J Gastroenterol 1990;25:45-53.

10. Burbol PG, Lygren I, Waldum HL, Jorde R. The effect of duodenal infusion of bile on plasma VIP, GIP, and secretin and on duodenal bicarbonate secretion. Scand $\mathbf{J}$ Gastroenterol 1980;15:1007-11.

11. Bondesen S, Christensen H, Lindorff-Larsen K, Schaffalitzky de Muckadell OB. Plasma secretin in respone to pure bile salts and endogenous bile in man. Dig Dis Sci 1985;30:440-4.

12. Hanssen LE, Hotz J, Layer P, Goebell H. Bile-stimulated secretin release in cats. Scand J Gastroenterol 1986;21:886-90.

13. Hanssen LE. Pure synthetic bile salts release immunoreactive secretin in man. Scand J Gastroenterol 1980;15:461-3.

14. Fiedler F, Riepl RL, Scharl A, Teufel J, Hempen I, Lehnert P. Effekt von Glyko-bzw. Taurodeoxycholat im Duodenum auf das exokrine Pankreas und die Freisetzung von GI-Peptiden. Z Gastroenterol 1989;27:557.

15. Hanssen LE, Hotz J, Hartmann W, Nehls W, Goebell H. Immunoreactive secretin release following taurocholate perfusions of the cat duodenum. Scand J Gastroenterol 1980;15:8995 .

16. Miyasaka K, Funakoshi A, Shikado F, Kitani K. Stimulatory and inhibitory effects of bile salts on rat pancreatic secretion. Gastroenterology 1992;102:598-604.

17. Schaffalitzky de Muckadell OB, Fahrenkrug J, Nielsen J, Westphall I, Worning $\mathrm{H}$. Meal-stimulated secretin release in man: effect of acid and bile. Scand J Gastroenterol 1981;16:9818.

18. Domschke S, Domschke W, Rösch W, et al. Vasoactive intestinal peptide: a secretin-like partial agonist for pancreatic secretion in man. Gastroenterology 1977;73:478-80.
19. Konturek SJ, Thor P, Dembinski A, Krol R. Comparison of secretin and vasoactive intestinal peptide on pancreatic secretion in dogs. Gastroenterology 1975;68:1527-35.

20. Larsson LI, Fahrenkrug J, Schaffalitzky de Muckadell O, Sundler $F$, Håkanson $R$, Rehfeld JF. Localization of vasoactive intestinal peptide (VIP) to central and peripheral neurons. Proc Natl Acad Sci 1976;73:3197-200.

21. Holst JJ. Neuronal control of pancreatic exocrine secretion. Eur J Clin Invest 1990;20 Suppl 1:S33-9.

22. Riepl RL, Fiedler F, Ernstberger M, Lehnert P. Effect of Nataurodeoxycholate and L-phenylalanine on ecbolic pancreatic secretion and on plasma cholecystokinin in man. Eur $\mathrm{J}$ Clin Invest 1992;22 (II):A22.

23. Burhol PG, Rayford PL, Jorde R, Waldum HL, Schulz TB, Thompson JC. Radioimmunoassay of plasma cholecystokinin (CCK), duodenal release of CCK, diurnal variation of plasma CCK, and immunoreactive plasma CCK components in man. Hepatogastroenterol 1980;27:300-9.

24. Burhol PG, Jenssen TG, Lygren I, Schulz TB, Jorde R, Waldum $\mathrm{HL}$. Iodination with iodo-gen and radioimmunoassay of cholecystokinin (CCK) in acidified plasma, CCK release, and molecular CCK components in man. Digestion 1982;23:156-68.

25. Nakaba H, Sakamoto T, Hamaji M, Kawashima M, Hamaoka T. Cholecystokinin secretion after pancreaticoduodenostomy. Biomed Res 1989;9:189.

26. Koop I, Koop H, Gerhardt C, Schafmayer A, Arnold R. Do bile acids exert a negative feedback control of cholecystokinin release? Scand J Gastroenterol 1989;24:315-20.

27. Nustede R, Schmidt WE, Köhler H, Schafmayer A. On the relationship between plasma CCK concentrations and the intraduodenal presence of bile. Digestion 1990;46:80.

28. Gomez G, Lluis F, Guo Y-S, Greeley GH, Townsend CM, Thompson JC. Bile inhibits release of cholecystokinin and neurotensin. Surgery 1986;100:363-8.

29. Davies HA, Wheeler MH, Psaila J, et al. Bile exclusion from the duodenum. Its effect on gastric and pancreatic function in the dog. Dig Dis Sci 1985;30:954-60.

30. Malagelada J-R, Go VLW, DiMagno EP, Summerskill WHJ. Interactions between intraluminal bile acids and digestive products on pancreatic and gallbladder function. J Clin Invest $1973 ; 52: 2160-5$

31. Gomez G, Upp JR, Lluis F, et al. Regulation of the release of cholecystokinin by bile salts in dogs and humans. Gastroenterology 1988;94:1036-46.

32. Koop I, Dorn S, Koop H, Gerhardt C, Arnold R. Intraduodenal cholestyramine and bile acids: effect on plasma-cholecystokinin (CCK), pancreatic polypeptide (PP), pancreatic and biliary secretion in man. Biomed Res 1988;9:42.

33. Fölsch UR. Feedback regulation of pancreatic exocrine secretion in animal and man. Eur J Clin Invest 1990;20 Suppl 1:S404.

34. Shiratori K, Chen YF, Chey WY, Lee KY, Chang T-M. Mechanism of increased exocrine pancreatic secretion in pancreatic juice-diverted rats. Gastroenterology 1986;91:1171-8.

35. Nakamura R, Miyasaka K, Funakoshi A, Kitani K. Interactions between bile and pancreatic juice diversions on cholecystokinin release and pancreas in conscious rats. Proc Soc Exp Biol Med $1989 ; 192: 182-6$.

36. Nakamura R, Miyasaka K, Kuyama Y, Kitani K. Luminal bile regulates cholecystokinin release in conscious rats. Dig Dis Sci 1990;33:53-60.

37. Baba N, Suzuki T, Tobe $T$, et al. Influence of obstructive jaundice on pancreatic growth and on basal plasma levels of cholecystokinin and gastrin in rats. Dig Dis Sci 1986;31:123341.

38. Ohta H, Guan D, Tawil T, Liddle RA, Green GM. Regulation of plasma cholecystokinin levels by bile and bile acids in the rat. Gastroenterology 1990;99:819-25.

39. Gomez G, Townsend CM, Green DW, Rajaraman S, Greeley GH, Thompson JC. Reduced cholecystokinin mediates the inhibition of pancreatic growth induced by bile salts. Am J Physiol 1990;259:G86-92.

40. Grundy SM. Treatment of hypercholesterolemia by interference 
with bile acid metabolism. Arch Intern Med 1972;130:638-48.

41. Koop I, Fellgiebel A, Koop H, Schafmayer A, Arnold R. Effect of cholestyramine on plasma cholecystokinin and pancreatic polypeptide levels, and exocrine pancreatic secretion. Eur J Clin Invest 1988;18:517-23.

42. Gomez G, Townsend CM, Maani R, Singh P, Greeley GH, Thompson JC. Down-regulation of pancreatic growth and gallbladder contractility by bile salts. Am J Surg 1989;157:206.

43. Koop I, Lindenthal M, Schade T, Adler G. Cholestyramineinduced increase in pancreatic growth and proteases content is mediated by cholecystokinin (CCK). Gastroenterology 1989; 96:A268.

44. Koop I, Dorn S, Koop H, Gerhardt C, Arnold R. Intraduodenales Cholestyramin und Gallensäuren: Effekt auf die stimulierte Plasma-CCK-, Plasma-PP-, Pankreasenzym- und Gallesekretion. Z Gastroenterol 1988:26:480.

45. Koop I. Role of bile acids in the control of pancreatic secretion and CCK release. Eur J Clin Invest 1990;20 Suppl 1:S51-7.

46. Beauchamp RD, Townsend CM. Neurotensin. In: Thompson JC, Greeley GH, Townsend CM, editors. Gastrointestinal endocrinology. New York: McGraw-Hill, 1987:301-10.

47. Feurle GE, Hofmann G. Carraway R, Baca I. Reproduction of postprandial neurotensin plasma levels by intravenous neurotensin and the effect of neurotensin on exocrine pancreatic secretion in humans. Pancreas 1986;1:329-34.

48. Koop I, Witzleb S, Lindenthal M, Adler G, Nustede R, Arnold $R$. Influence of cholecystokinin (CCK) receptor blockade on bile acid-induced changes in plasma CCK, neurotensin and pancreatic enzyme output. Digestion 1990;46 Suppl 1:58.

49. Khalil T, Alinder G, Rayford PL. Gastric inhibitory polypeptide. In: Thompson JC, Greeley GH, Townsend CM, editors. Gastrointestinal endocrinology. New York: McGraw-Hill, 1987:249-59.

50. Flaten O, Hanssen LE, Osnes M, Myren J. Plasma concentrations of gastric inhibitory polypeptide after intraduodenal infusion of cattle bile and synthetic bile salts in man. Scand $\mathbf{J}$ Gastroenterol 1981;16:1073-5.

51. Björnsson OG, Fletcher DR, Christofides ND, Bloom SR, Chadwick VS. Duodenal perfusion with sodium taurocholate inhibits biliary but not pancreatic secretion in man. Clin Sci 1982;62:651-9.

52. Imamura M. Ohneda A, Sato T, Tsuchiya T, Kameyama J. Effect of bile infusion into the upper jejunum on gut hormone release in dogs. Surg Gastroenterol 1983;2:97-103.

53. Imamura $M$, Takahashi $M$, Sasaki I, Yamauchi $H$, Sato $T$. Effects of the pathway of bile flow on the digestion of fat and the release of gastrointestinal hormones. Am J Gastroenterol 1988;83:386-92.

54. Petersen H, Berstad A. The interaction between pentagastrin and cholecystokinin on pancreatic secretion in man. Scand $\mathrm{J}$ Gastroenterol 1973;8:257

55. Londong W, Frühauf S, Forell MM. Verhalten von Serumgastrin nach intraduodenaler Gabe von Galle. Verh Dtsch Ges Inn Med 1974;80:516-8.

56. Londong W, Frühauf S, Klewar G, Otte M, Forell MM. Weitere Untersuchungen zur Gastrinfreisetzung nach intraduodenaler Gabe von Galle. Verh Dtsch Ges Inn Med 1976;82:991-4.

57. Rhodes J, Davies HA, Wheeler MH, et al. Bile diversion from the duodenum: its effect on gastric and pancreatic function. Scand J Gastroenterol 1984;19 Suppl 92:221-3.

58. Tsuchiya $T$, Sasaki I, Imamura $M$, Naito $H$. The influence of biliary diversion on canine gastric acid secretion and gut hormones. J Jpn Surg Soc 1986;87:659-70.

59. Layer P, von der Ohe M, Müller MK, Beglinger C. Effects of somatostatin on the exocrine pancreas. Scand J Gastroenterol 1991;26:129-36.

60. Fiedler F, Riepl RL, Teufel J, Lehnert P. The effect of intraduodenal bile and Na-taurodeoxycholate on plasma concentrations of somatostatin and VIP in man. Eur J Clin Invest 1991;21(II):14

61. Burhol PG, Lygren I, Jenssen TG, Florholmen J, Jorde R. Somatostatin release and plasma molecular somatostatin components in man. Acta Physiol Scand 1984;121:223-8.

62. Chayvialle J-A, Miyata M, Rayford PL, Thompson JC. Effects of test meal, intragastric nutrients, and intraduodenal bile on plasma concentrations of immunoreactive somatostatin and vasoactive intestinal peptide in dogs. Gastroenterology 1980; $79: 844-52$.

63. Sakamoto T, Lluis F, Rayford PL. Pancreatic polypeptide. In: Thompson JC, Greeley GH, Townsend CM, editors. Gastrointestinal endocrinology. New York: McGraw-Hill, 1987: 273-85.

64. Singer MV, Niebel W, Uhde KH, Hoffmeister D, Goebell H. Dose-response effects of atropine on pancreatic response to secretin before and after truncal vagotomy. Am J Physiol 1985;248:G532-8.

65. Chey WY, Kim MS, Lee KY. Influence of the vagus nerve on release and action of secretin in dog. J Physiol (Lond) 1979;293:435-46.

66. Forell MM, Stahlheber H, Otte M, Görlich HJ. Die Abhängigkeit der Pankressekretion von der Gallensekretion nach Cholecystokinin/Pankreozymin. Verh Dtsch Ges Inn Med 1969;75:645-7.

67. Forell MM. Bile salts as stimulants of pancreatic secretion. In: Anderson S, editor. Frontiers in gastrointestinal hormone research. Stockholm: Almqvist \& Wiksell, 1973:277-82.

68. Schwartz TW. Pancreatic polypeptide: a hormone under vagal control. Gastroenterology 1983;85:1411-25.

69. Lonovics J, Guzman S, Devitt P, et al. Release of pancreatic polypeptide in humans by infusion of cholecystokinin. Gastroenterology 1980;79:817-22.

70. Singer MV, Niebel W, Hoffmeister D, Goebell H. Are there still enteropancreatic reflexes after truncal vagotomy? Gastroenterology 1983;84:1312.

71. Holst JJ, Fahrenkrug J, Knuhtsen S, Jensen SL, Poulsen SS, Nielsen OV. Vasoactive intestinal polypeptide (VIP) in the pig pancreas: role of VIPergic nerves in control of fluid and bicarbonate secretion. Regul Peptides 1984;8:245-59.

72. Fahrenkrug J, Schaffalitzky de Muckadell OB, Holst JJ, Jensen $\mathrm{SL}$. Vasoactive intestinal polypeptide in vagally mediated pancreatic secretion of fluid and $\mathrm{HCO}_{3}$. Am J Physiol 1979;237: E535-40.

73. Holst JJ, Knuhtsen S, Jensen SL, Fahrenkrug J, Larsson L-I, Nielsen OV. Interrelation of nerves and hormones in stomach and pancreas. Scand J Gastroenterol 1983;18 Suppl 83:85-99.

74. Lehnert P, Forell MM, Jaeger E, Moroder L, Wünsch E. Hydrokinetic activity of secretin and secretin analogues, modified in the $\mathrm{N}$-terminal sequence, and of vasoactive intestinal peptide in the dog pancreas. Digestion 1981;22:85-8.

75. Greeley GH, Newmann J. Enteric bombesin-like peptides. In: Thompson JC, Greeley GH, Townsend CM, editors. Gastrointestinal endocrinology. New York: McGraw-Hill, 1987: 323-9. 